Volume 1 Issue 1 (2017) Pages 12 - 18

Jurnal Obsesi : Jurnal Pendidikan Anak Usia Dini

DOI: $10.31004 /$ obsesi.v1i1.33

\title{
Penggunaan Media Gambar Seri Untuk Meningkatkan Kemampuan Berbicara Anak Usia Dini
}

\author{
Iis Aprinawati ${ }^{\bowtie}$ \\ Prodi Pendidikan Guru Sekolah Dasar Fakultas Ilmu Pendidikan \\ Universitas Pahlawan Tuanku Tambusai
}

\begin{abstract}
Abstrak
Salah satu karakteristik anak usia dini adalah memiliki rasa antusias dan ingin tahu yang kuat terhadap banyak hal di sekitarnya. Rasa ingin tahu tersebut dapat dimunculkan dengan menggunakan media. Media merupakan sarana pembelajaran yang dapat memunculkan minat siswa untuk belajar karena media merupakan segala sesuatu yang dapat dipergunakan untuk menyalurkan pesan, merangsang pikiran, perhatian, dan kemauan siswa sehingga dapat terlibat dalam proses pembelajaran. Media gambar seri memiliki suatu urutan gambar sehingga dapat merangsang pikiran anak untuk berbicara dan menghasilkan cerita yang berkesinambungan. Tujuan penelitian menjelaskan media gambar berseri ini dapat meningkatkan minat siswa untuk berbicara sehingga kemampuan berbicara anak usia dini semakin meningkat. Adapun metode penelitian yang digunakan dalam penelitian ini adalah kajian pustaka yaitu rangkaian kegiatan yang berkenaan dengan metode pengumpulan data pustaka, membaca dan mencatat serta mengelola bahan penelitian. Hasil Penelitian yang diperoleh dengan menggunakan media gambar seri dapat mengembangkan potensi perkembangan berbicara anak dan menambah penguasaan kosakatanya.
\end{abstract}

Kata Kunci: Media Gambar Seri, Kemampuan berbicara, Anak usia dini

\begin{abstract}
One of the characteristics of early childhood is to have a strong sense of enthusiasm and curiosity towards many things around it. Curiosity can be raised using the media. Media is a means of learning that can bring the interest of students to learn because the media is everything that can be used to channel the message, stimulate the mind, attention, and willingness of students to be involved in the learning process. The series image media has a sequence of images that can stimulate the child's mind to speak and produce a continuous story. The purpose of the study explains the media of this series can increase the students' interest to speak so that the ability to speak early child is increasing. The research method used in this study is literature review is a series of activities related to the method of collecting data library, reading and recording and managing research materials. Research results obtained by using a series of drawing media can develop the potential for child speech development and increase vocabulary mastery.
\end{abstract}

Keywords : Media Picture Series, Speech, Early Childhood

@Jurnal Obsesi Prodi PG-PAUD FIP UPTT 2017

$\triangle$ Corresponding author :

Address : Jalan Tuanku Tambusai Bangkinang

Email : aprinawatiiis@gmail.com

ISSN 2356-1327 (Media Cetak)

ISSN 2549-8959 (Media Online) 


\section{PENDAHULUAN}

Pendidikan Anak Usia Dini (PAUD) adalah pendidikan sebelum jenjang pendidikan dasar yang merupakan suatu upaya pembinaan pada anak usia lahir sampai usia 6 tahun yang dilakukan melalui pemberian rangsangan pendidikan untuk membantu pertumbuhan dan perkembangan jasmani dan rohani agar anak memiliki kesiapan dalam pendidikan lebih lanjut. PAUD dititik beratkan pada pertumbuhan dan perkembangan fisik, kecerdasan sosial emosional, untuk memenuhi hak belajar anak, kegiatan pembelajaran dilakukan dalam keadaan menyenangkan, kognitif, dan memungkinkan anak menjadi termotivasi dan antusias (Hasan, 2011)

\section{Pendidikan Anak Usia Dini} (PAUD) adalah upaya pembinaan yang ditujukan kepada anak sejak lahir sampai dengan usia 6 tahun, yang dilakukan melalui pemberian rangsangan pendidikan untuk membantu pertumbuhan dan perkembangan jasmani dan rohani agar anak memiliki kesiapan dalam memasuki pendidikan lebih lanjut (UU Nomor 20 Tahun 2003). Pendidikan anak usia dini bertujuan untuk mengembangkan potensi secara optimal.

Salah satu potensi yang harus dikembangkan sejak dini adalah keterampilan berbahasa, salah satunya berbicara. Berbicara merupakan bentuk komunikasi secara lisan yang berfungsi untuk menyampaikan maksud dengan lancar, menggunakan kata-kata, dan menggunakan kalimat dengan jelas. Perkembangan bahasa anak usia 3-5 tahun sudah dapat berbicara dengan baik.

Menurut (Carool, Seefelt \& Barbara A, 2008) pada usia 4 tahun perkembangan kosaskata anak mencapai 4.000-6.000 kata dan berbicara dalam kalimat 5-6 kata. Usia 5 tahun perbendaharaan kata terus bertambah mencapai 5.000 sampai 8.000 kata. Kalimat yang dipakaipun semakin kompleks.
Keterbatasan anak dalam mengungkapkan bahasa lisannya di kelas dikarenakan metode yang digunakan belum sesuai dengan perkembangan bahasa anak. Bahasa dapat memberikan suatu kegiatan yang menarik dan menyenangkan sehingga dapat memberikan dorongan perkembangan bahasa karena anak harus mampu mengungkapkan diri dengan kata-kata, untuk mendorong kata-kata, maka kegiatan tersebut harus dilaksanakan melalui permainan deskriptif. Permainan deskriptif adalah permainan yang menuntut anakanak untuk menguraikan benda dan mendorong anak untuk mencari kata-kata sehingga dapat membantu mereka untuk berbicara dan berpikir dengan lebih jelas, salah satu contohnya permainan yaitu dengan memberikan media gambar seri.

Media gambar seri merupakan media pembelajaran berupa gambar yang mengandung cerita dengan beberapa urutan sehingga antara gambar yang satu dengan gambar yang lainnya membentuk satu kesatuan yang mengambarkan peristiwa dalam bentuk cerita tersusun. (Azhar Arsyad, 2002).

Dengan menggunakan media gambar seri dapat mengembangkan potensi perkembangan berbicara anak, yaitu dengan cara anak dapat menyampaikan pesan terdiri dari dua atau tiga kata dan dapat memunculkan kalimat-kalimat yang lebih rumit.

\section{METODOLOGI PENELITIAN}

Penelitian ini menggunakan kajian pustaka, kajian pustaka dalam suatu penelitian ilmiah adalah salah satu bagian penting dari keseluruhan langkah-langkah metode penelitian.

$$
\text { Menurut Zed }
$$

mengemukakan riset pustaka tidak hanya sekedar urusan membaca dan mencatat literatur atau buku-buku sebagaimana yang sering dipahami banyak orang selama ini. apa yang disebut riset pustaka atau sering disebut studi pustaka, ialah rangkaian kegiatan yang berkenaan dengan metode 
pengumpulan data pustaka, membaca dan mencatat serta mengelola bahan penelitian.

Ada 3 alasan mengapa menggunakan penelitian pustaka yaitu: 1) persoalan penelitian tersebut hanya bisa dijawab lewat penelitian pustaka, 2) studi pustaka diperlukan sebagai salah satu tahap tersendiri, yaitu studi pendahuluan untuk memahami lebih dalam gejala baru yang tengah berkembang di lapangan atau dalam masyarakat, 3) data pustaka tetap andal untuk menjawab persoalan penelitiannya.

Dengan demikan, riset pustaka dengan cara memanfaatkan sumber perpustakaan untuk memperoleh data penelitiannya sehingga dengan riset pustaa dapat membatasi kegiatan hanya pada bahan-bahan koleksi perpustakaan tanpa memerlukan riset lapangan.

\section{HASIL DAN PEMBAHASAN Media}

Kata media berasal dari bahasa latin medius yang secara harfiah berarti tengah pelantara atau pengantar. Mengenai istilah, media yang digunakan untuk mendukung proses belajar mengajar, ada beberapa ahli yang menyebutnya dengan istilah media pembelajaran, ada juga yang menyebut dengan media pendidikan. Pada dasarnya semua istilah itu mengadung konsep/pengertian yang sama, namun berbeda dalam pengunaan istilah saja. Media merupakan parantara suatu hal dengan hal yang lainnya. Media biasanya digunakan sebagai sarana untuk mempermudah dan mempercepat aktivitas pembelajaran baik di sekolah, maupun di tempat - tempat lainnya.

Salah satu upaya guru untuk mengatasi kurangnya minat dan semangat anak dalam belajar adalah dengan menggunakan media karena media bermanfaat untuk mengatasi keterbatasan ruang, waktu, dan daya indera

(Djamarah, Syaiful Bahri dan Zain, 2002) menyatakan bahwa media merupakan wahana penyalur informasi belajar atau penyalur pesan. Bila media adalah sumber belajar, maka secara luas media dapat diartikan dengan manusia, benda, ataupun peristiwa yang memungkinkan anak didik memperoleh pengetahuan dan keterampilan.

Menurut (Azhar Arsyad, 2002) pengertian media adalah alat bantu pada proses belajar baik di dalam maupun di luar kelas. Alat bantu tersebut bisa berbentuk manusia, cetak, visual, audiovisual, dan komputer. Hamdani (2011: 244) menyimpulkan bahwa media pembelajaran adalah segala sesuatu yang dapat menyalurkan pesan, merangsang pikiran, perasaan, dan kemauan siswa sehingga mendorong terciptanya proses belajar pada diri siswa. Gerlach dan Elly (dalam Arsyad 2003: 3) mengatakan bahwa media apabila dipahami secara garis besar adalah manusia, materi, atau kejadian yang membangun kondisi yang membuat siswa mampu memperoleh pengetahuan, keterampilan, atau sikap. Pernyataan tersebut menunjukkan bahwa media sangat penting dalam proses pembelajaran dengan media peserta didik akan lebih mudah memahami pelajaran. Gagne dan Briggs (dalam Arsyad 2003: 4) mengatakan bahwa media pembelajaran meliputi alat yang secara fisik digunakan untuk menyimpan isi materi pelajaran. Sehingga dapat disimpulkan bahwa media adalah alat, metode, dan teknik yang digunakan untuk menyampaikan materi pelajaran yang dapat menyajikan perangsang siswa dalam proses pembelajaran.

(Angkowo, Robertes dan Kosasih, 2007) Media juga dapat diartikan sebagai segala sesuatu yang dapat dipergunakan untuk menyalurkan pesan, merangsang pikiran, perasaan, perhatian, dan kemamuan siswa, sehingga dapat terdorong terlibat dalam proses pembelajaran.

Media memungkinkan bersatunya dua hal yang berbeda, menjadi pengantar sesuatu, dan membuat sesuatu menjadi lebih mudah digunakan, dapat pula berupa dalam bidang pendidikan, kemunculan media (dalam hal ini adalah media pembelajaran) salah satunya ditunjukan agar siswa lebih termotifasi pada pembelajaran yang diberikan. Media 
tersebuat dapat berupa hal-hal sederhana seperti gambar, poster, pamflet yang mudah ditemukan, ekonomis alat-alat elektronik yang berteknologi tinggi.

Dalam Buku Pengantar Ilmu Komunikasi (Cangara, 2006 : 119), media adalah alat atau sarana yang digunakan untuk menyampaikan pesan dari komunikator kepada khalayak. Ada beberapa pakar psikologi memandang bahwa dalam komunikasi antarmanusia, maka media yang paling dominasi dalam berkomunikasi adalah pancaindera manusia seperti mata dan telinga. Pesan pesan yang diterima selanjutnya oleh pancaindera selanjutnya diproses oleh pikiran manusia untuk mengontrol dan menentukan sikapnya terhadap sesuatu, sebelum dinyatakan dalam tindakan.

Beberapa pendapat ahli di atas, maka dapat disimpulkan bahwa media adalah alat, sarana, perantara, dan penghubung untuk menyebar, membawa atau menyampaikan sesuatu pesan (message) dan gagasan kepada penerima. Dengan demikian, media pendidikan adalah segala sesuatu yang dapat digunakan untuk menyalurkan pesan sehingga dapat merangsang pikiran, perasaan, perbuatan, minat serta perhatian siswa sedemikian rupa sehingga proses belajar mengajar terjadi pada diri siswa.

\section{Gambar Seri}

Media gambar berseri adalah media yang berisi dengan gambar-gambar yang saling berkaitan satu dengan yang lainnya. hal tersebut diperkuat menurut (Arsyad, 2002) bahwa gambar seri merupakan rangkaian kegiatan atau cerita yang disajikan secara berururtan. Gambar seri adalah suatu urutan dari gambar yang mengikuti suatu percakapan dalam hal memperkenalkan ataupun menyajikan arti yang terdapat pada gambar tersebut. Disebut dengan gambar seri, sebab gambar satu dengan gambar lainnya mempunyai hubungan atau saling berkaitan.Tujuannya adalah supaya media gambar tersebut dapat membantu dalam menyajikan suatu kejadian atau peristiwa yang kronologisnya dengan menghadirkan benda, orang dan juga latar.

Gambar seri biasa disebut dengan istilah gambar bersambung. Media gambar seri merupakan media grafis yang digunakan untuk menerangkan suatu rangkaian perkembangan, sebab setiap seri media gambar bersambung dan selalu terdiri dari sejumlah gambar. Gambargambar tersebut membentuk suatu cerita apabila gambar-gambar dipadukan dan diurutkan secara sistematis sehingga menjadi urutan cerita yang bermakna dan memiliki arti. Gambar seri merupakan kumpulan gambar yang menunjuk satu peristiwa yang utuh. Gambar tersebut bisa dalam bentuk kartu yang terpisah atau dalam satu lembaran yang utuh. Cara menggunakannya bisa satu-satu atau sekaligus ditunjukkan kepada siswa, tergantung materi yang akan disampaikan.

Media gambar seri merupakan jenis media visual atau hanya mempunyai unsur gambar. Adapun fungsi media visual dalam pembelajaran menurut Levie \& Lentz (dalam Arsyad, 2011: 16), yaitu: "fungsi afensi, fungsi afektif, fungsi kognitif, dan fungsi kompensatoris". Keempat fungsi media visual tersebut akan diuraikan sebagai berikut:

1. Fungsi atensi dari media visual, seperti media gambar seri yang dapat menarik dan mengarahkan perhatian siswa untuk berkonsentrasi terhadap isi pelajaran yang ditampilkan atau menyertai teks materi pelajaran. Contohnya, ketika siswa bosan mendengarkan ceramah guru, maka guru memperlihatkan gambar-gambar seri yang berkaitan dengan materi pelajaran. Ini dapat menarik perhatian dan konsentrasi siswa terhadap materi pelajaran karena adanya media yang dapat dilihat langsung. 2. Fungsi afektif dari media visual, seperti media gambar seri yang diperagakan oleh guru akan menggugah emosi dan sikap siswa, misalnya informasi yang menyangkut masalah sosial atau ras dalam kehidupan sehari-hari. Kemampuan belajar siswa akan lebih meningkat dengan menggunakan gambar seri. Penggunaan gambar seri diupayakan menggugah 
perasaan siswa tentang berbagai peristiwa melalui gambar-gambar yang disajikan secara berseri.

3. Fungsi kognitif dari media visual, seperti gambar seri akan dapat memperlancar pencapaian tujuan untuk memahami dan mengingat informasi atau pesan yang terkandung dalam gambar. Jadi, penggunaan media gambar seri sebagai media visual akan meningkatkan daya pikir siswa terhadap materi pelajaran.

4. Fungsi kompensatoris dari media visual, seperti media gambar seri akan memberikan konteks untuk memahami teks dan membantu siswa yang lemah dalam membaca untuk mengorganisasikan informasi dalam teks dan dapat mengingat kembali. Hal ini sangat penting dalam mengakomodasi siswa yang lemah dan lambat dalam menerima dan memahami isi pelajaran yang disajikan dengan teks atau disajikan secara verbal, karena murid dapat melihat secara langsung dan mengaitkan dengan materi pelajaran.

Berdasarkan pendapat di atas, jelas bahwa media memiliki fungsi yang sangat luas dan penting, terlebih dalam dunia pendidikan, sebagaimana digunakan guru dalam proses pembelajaran. Walaupun dalam pengadaan dan pemanfaatannya senantiasa masih menghadapi berbagai kendala, baik karena tidak disiapkan oleh pihak sekolah maupun keterbatasan kemampuan guru dalam membuat dan menggunakan media pembelajaran, seperti gambar seri.

\section{Kemampuan Berbicara}

Bicara adalah bentuk bahasa yang menggunakan artikulasi atau kata-kata yang digunakan untuk menyampaikan maksud (Hurlock, 1978). Melalui berbicara maka akan terjadi komunikasi antara anak yang satu dengan anak lainnya. Berbicara pada anak perlu dikembangkan dan dilatih secara terus menerus agar perkembangan anak terutama dalam hal berbicara untuk komunikasi dapat berkembang dengan optimal. Dari segi komunikasi, menyimak dan berbicara disekolah sering kurang dianggap perlu dan kurang ditangani serius, sebab siswa dianggap sudah bisa berbicara dan dapat dipelajari secara informal diluar sekolah karena sudah dapat berbicara itulah guru menganggap tidak perlu memberikan penekanan kegiatan berbicara pada anak karena biasanya guru lebih menekankan kepada membaca dan menulis.

Kemampuan berbicara merupakan kemampuan awal yang harus dimiliki anak untuk dapat berkomunikasi dengan baik. Untuk itu, kemampuan berbicara merupakan kemampuan pada tahap awal untuk bisa berkomunikasi dengan baik dan benar.

Definisi berbicara juga dikemukakan oleh Brown dan Yule dalam Puji Santosa, dkk (2006:34). Berbicara adalah kemampuan mengucapkan bunyibunyi bahasa untuk mengekspresikan atau menyampaikan pikiran, gagasan atau perasaan secara lisan. Pengertian ini pada intinya mempunyai makna yang sama dengan pengertian yang disampaikan oleh Tarigan yaitu berbicara berkaitan dengan pengucapan kata-kata.(Tarigan, 2008)

(Haryadi dan Zamzani, 2000) mengemukakan bahwa secara umum berbicara dapat diartikan sebagai suatu penyampaian maksud (ide, pikiran, isi hati) seseorang kepada orang lain dengan menggunakan bahasa lisan sehingga maksud tersebut dapat dipahami orang lain. Pengertian ini mempunyai makna yang sama dengan kedua pendapat yang diuraikan di atas, hanya saja diperjelas dengan tujuan yang lebih jauh lagi yaitu agar apa yang disampaikan dapat dipahami oleh orang lain.

Selanjutnya, St. Y. Slamet dan Amir (1996: 64) mengemukakan pengertian berbicara sebagai keterampilan menyampaikan pesan melalui bahasa lisan sebagai aktivitas untuk menyampaikan gagasan yang disusun serta dikembangkan sesuai dengan kebutuhan penyimak. Pengertian ini menjelaskan bahwa berbicara tidak hanya sekedar mengucapkan kata-kata, tetapi menekankan pada penyampaian gagasan yang disusun dan dikembangkan sesuai 
dengan kebutuhan penyimak atau penerima informasi atau gagasan.

Berdasarkan beberapa pendapat ahli yang telah diuraikan di atas dapat disimpulkan bahwa berbicara ialah kemampuan mengucapkan kata-kata dalam rangka menyampaikan atau menyatakan maksud, ide, gagasan, pikiran, serta perasaan yang disusun dan dikembangkan sesuai dengan kebutuhan penyimak agar apa yang disampaikan dapat dipahami oleh penyimak.

Tujuan utama berbicara adalah untuk berkomunikasi. Komunikasi merupakan pengiriman dan penerimaan pesan atau berita antara dua orang atau lebih sehingga pesan yang dimaksud dapat dipahami. Oleh karena itu, agar dapat menyampaikan pesan secara efektif, pembicara harus memahami apa yang akan disampaikan atau dikomunikasikan. Tarigan juga mengemukakan bahwa berbicara mempunyai tiga maksud umum yaitu untuk memberitahukan dan melaporkan (to inform), menjamu dan menghibur (to entertain), serta untuk membujuk, mengajak, mendesak dan meyakinkan (to persuade).(Tarigan, 2008)

Pemberian stimulus untuk meningkatkan keterampilan berbicara anak, selain dengan melatih anak berbicara dengan baik dan benar juga dapat melalui pembacaan-pembacaan cerita yang menarik. (Pratama, Abidin, \& Ismail, 2016)

Gorys Keraf dalam St. Y. Slamet dan Amir (1996: 46-47) mengemukakan tujuan berbicara diantaranya adalah untuk meyakinkan pendengar, menghendaki tindakan atau reaksi fisik pendengar, memberitahukan, dan menyenangkan para pendengar. Pendapat ini tidak hanya menekankan bahwa tujuan berbicara hanya untuk memberitahukan, meyakinkan, menghibur, namun juga menghendaki reaksi fisik atau tindakan dari si pendengar atau penyimak.

Tim LBB SSC Intersolusi (2006:84) berpendapat bahwa tujuan berbicara ialah untuk: (1) memberitahukan sesuatu kepada pendengar, (2) meyakinkan atau mempengaruhi pendengar, dan (3) menghibur pendengar. Pendapat ini mempunyai maksud yang sama dengan pendapat-pendapat yang telah diuraikan di atas.

Berdasarkan beberapa pendapat yang telah dikemukakan di atas, dapat disimpulkan bahwa tujuan berbicara yang utama ialah untuk berkomunikasi, sedangkan tujuan berbicara secara umum ialah untuk memberitahukan atau melaporkan informasi kepada penerima informasi, meyakinkan atau mempengaruhi penerima informasi, untuk menghibur, serta menghendaki reaksi dari pendengar atau penerima informasi.

\section{Anak Usia Dini}

Pendidikan anak usia dini (PAUD) adalah jenjang pendidikan sebelum jenjang pendidikan dasar yang merupakan suatu upaya pembinaan yang ditujukan bagi anak sejak lahir sampai dengan usia enam tahun yang dilakukan melalui pemberian rangsangan pendidikan untuk membantu pertumbuhan dan perkembangan jasmani dan rohani agar anak memiliki kesiapan dalam memasuki pendidikan lebih lanjut, yang diselenggarakan pada jalur formal, nonformal, dan informal.

\begin{tabular}{llr}
\multicolumn{2}{c}{ Pendidikan anak usia dini } \\
merupakan salah satu bentuk \\
penyelenggaraan pendidikan
\end{tabular}
menitikberatkan pada peletakan dasar ke arah pertumbuhan dan 5 perkembangan, yaitu: perkembangan moral dan agama, perkembangan fisik (koordinasi motorik halus dan kasar), kecerdasan/kognitif (daya pikir, daya cipta), sosio emosional (sikap dan emosi) bahasa dan komunikasi, sesuai dengan keunikan dan tahap-tahap perkembangan sesuai kelompok usia yang dilalui oleh anak usia dini seperti yang tercantum dalam Permendiknas nomor 58 tahun 2009.

Ada dua tujuan diselenggarakannya pendidikan anak usia dini yaitu:

1. Tujuan utama: untuk membentuk anak Indonesia yang berkualitas, yaitu anak yang tumbuh dan berkembang sesuai dengan tingkat perkembangannya sehingga memiliki kesiapan yang 
optimal di dalam memasuki pendidikan dasar serta mengarungi kehidupan pada masa dewasa.

2. Tujuan penyerta: untuk membantu menyiapkan anak mencapai kesiapan belajar (akademik) di sekolah, sehingga dapat mengurangi usia putus sekolah dan mampu bersaing secara sehat di jenjang pendidikan berikutnya.

Rentangan anak usia dini menurut Pasal 28 UU Sisdiknas No.20/2003 ayat 1 adalah 0-6 tahun. Sementara menurut kajian rumpun keilmuan PAUD dan penyelenggaraannya di beberapa negara, PAUD dilaksanakan sejak usia 0-8 tahun (masa emas).

Usia dini merupakan masa emas, masa ketika anak mengalami pertumbuhan dan perkembangan yang pesat, anak usia dini mampu mengembangkan pengetahuan yang sudah diketahui dengan pengetahuan baru yang diperolehnya, dan mengembangkan kemampuan memahami sesuatu dengan cara melihat bermacammacam hubungan antara suatu objek dengan objek yang lainnya berdasarkan perbedaan dan persamaan.

Anak mampu berfikir logis, kritis, memberikan alasan, memecahkan masalah dan menemukan hubungan sebab dan akibat, lalu anak akan berusaha memecahkan masalah dan memberikan alasan tersebut.

Anak usia dini merupakan landasan dari tiap-tiap perkembangan yang dijalani oleh manusia karena bagi anak, pendidikan yang tepat pada usia dini akan menjadi pondasi keberhasilannya pada masa yang akan datang. Seperti halnya mendidik anak usia dini bagaikan mengukir di atas batu, anak yang masih kecil seperti pada usia dini akan membutuhkan kesabaran dalam mendidiknya karena harus mengulangngulang konsep yang akan ditanamkan, namun begitu konsep tersebut sudah masuk, maka ia akan tertancap dengan kuat di sana, sulit hilang seperti ukiran di atas batu.

Berikut beberapa sifat dan karakteristik umum dari anak usia dini yang perlu diketahui adalah sebagai berikut: a) memiliki jiwa petualang atau sifat eksploratif, b) kaya akan daya imajinasi dan fantasi, c) mudah merasa frustasi, d) belum dapat berkonsentrasi untuk jangka waktu yang lama, e) rasa antusias dan ingin tahu yang kuat terhadap banyak hal di sekitarnya, f) Enerjik dan aktif, g) belum atau kurang memiliki pertimbangan dalam melakukan suatu tindakan, h) Merupakan fase yang sangat potensial untuk mengajar dan mendidik mereka.

Hubungan antara Penggunaan Gambar Seri dan meningkatkan kemampuan berbicara Anak Usia Dini

Pendidikan anak usia dini (PAUD) telah ditetapkan secara tegas dalam UU RI No. 20 tahun 2003 tentang sistem pendidikan nasional pada Bab 1 Pasal 1, butir 14 bahwa pendidikan anak usia dini adalah suatu upaya pembinaan yang ditunjukan kepada anak sejak lahir sampai dengan usia 6 tahun yang dilakukan melalui pemberian rangsangan pendidikan untuk membantu pertumbuhan dan perkembangan jasmani dan rohani agar anak memiliki kesiapan dalam memasuki pendidikan lebih lanjut.

Dalam Permen Diknas No. 58 tahun 2009 tentang kurikulum pembelajaran anak usia dini mempunyai tujuan untuk meningkatkan kualitas dan kuantitas anak usia dini pada semua aspek pengembangannya termasuk dalam keterampilan berbicara karena sesuai dengan karakteristiknya anak usia dini adalah anak yang baru memasuki proses rasa antusias dan ingin tahu yang kuat terhadap banyak hal di sekitarnya.

Media merupakan segala sesuatu yang dapat dipergunakan untuk menyalurkan pesan, merangsang pikiran, perasaan, perhatian, dan kemamuan siswa, sehingga dapat terdorong terlibat dalam proses pembelajaran. Maka dari itu penggunaan media gambar seri yang memiliki suatu urutan gambar yang mengikuti suatu percakapan dapat merangsang pikiran siswa sehingga siswa dapat mengutarakan media gambar seri melalui berbicara

Pendidikan anak usia dini bertujuan untuk mengembangkan semua aspek perkembangan yang dimiliki anak untuk memunculkan potensi secara optimal. Aspek perkembangan tersebut meliputi aspek nilai agama dan moral, aspek sosial emosional, aspek kognitif, aspek bahasa, dan aspek fisik motorik. Salah satu aspek perkembangan anak 
usia dini adalah bahasa. Bahasa sebagai sarana komunikasi dengan menyimbolkan pikiran dan perasaan untuk menyampaikan makna kepada orang lain. Melalui bahasa, anak dapat belajar mengungkapkan segala bentuk perasaan dalam hatinya sehingga orang lain dapat mengetahui apa yang dirasakan anak. Menurut Sunarto dan Agung Hartono (2008: 139) perkembangan bahasa anak dipengaruhi oleh beberapa faktor yaitu umur anak, kondisi lingkungan, kecerdasan anak, status sosial ekonomi dan kondisi fisik.

Bahasa merupakan alat komunikasi yang sangat penting dalam kehidupan manusia, karena berfungsi sebagai alat untuk menyatakan pikiran dan perasaan kepada orang lain. Berbagai hasil penelitian menunjukkan usia dini merupakan masa peka yang sangat penting bagi pendidikan anak, masa ini memerlukan rangsangan dan stimulasi yang tepat supaya kemampuan anak berkembang optimal, termasuk kemampuan berbahasa.

Menurut (Rosmala, 2005) bahwa perkembangan bahasanya, anak usia 4-5 tahun sudah dapat berbicara lancar dengan kalimat sederhana, sudah dapat menyebutkan sebanyak-banyaknya nama benda, binatang, tanaman yang mempunyai warna, bentuk, atau menurut ciri-ciri tertentu. Selanjutnya anak sudah bisa bercerita tentang kejadian disekitarnya secara sederhana. Anak sudah dapat mengurutkan dan menceritakan isi gambar seri (2-3 gambar). Kemudian anak sudah dapat bercerita tentang gambar yang dibuat sendiri serta anak dapat mengikuti 1 sampai dengan 2 perintah sekaligus. Kemudian anak dapat membuat sebanyak-banyaknya kata dari suku kata awal yang disediakan dalam bentuk lisan.

$$
\begin{array}{ccc}
\text { Perkembangan } & \text { bahasa anak dapat } \\
\text { mencapai optimal } & \text { sesuai } & \text { tahap }
\end{array}
$$
perkembangannya, bila diberikan stimulasi yang tepat dan sesuai. Anak perlu dilatih kemampuan berbahasanya salah satunya kemampuan berbicara secara terus menerus dengan tujuan membuat anak dapat berpikir dan lebih memiliki perbendaharaan kosakata yang banyak sehingga dalam menyampai-kan sesuatu anak tidak mengalami kesulitan.

$$
\text { Dengan mengubah kegiatan }
$$

pembelajaran menjadi lebih menarik, maka anak menjadi bersemangat dalam mengikuti pembelajaran dan tujuan guru untuk meningkatkan kemampuan berbicara anak dapat berhasil dan berjalan dengan maksimal. Salah satu kegiatan yang dapat mengembangkan dan menstimulasi kemampuan berbicara anak adalah dengan menggunakan media gambar seri yaitu media pembelajaran berupa gambar yang mengandung cerita dengan beberapa urutan sehingga antara cerita yang satu dengan gambar yang lainnya membentuk satu kesatuan yang mengambarkan peristiwa dalam bentuk cerita tersusun.

Hal-hal yang harus diperhatikan dalam kegiatan bercerita dalam penggunaan media gambar seri yaitu sebagai berikut:

1) orientasi lebih pada kaitan antara cerita dan tiap-tiap gambar, 2) sambil menunjukkan gambar, cerita dibacakan secara pelan (tidak tergesa-gesa), volume cukup, lafal jelas. 3) cerita diulang dengan melibatkan anak dan mengulas makna setiap gambar, 4) gambar dibuat agak besar, agar semua anak dapat melihat gambar tersebut. selain dibuat agak besar, gambar juga perlu pewarnaan yang menarik. 5) posisi gambar sejajar dengan jarak pandang anak. (Tadkiroatun, 2009)

Dengan demikian, menggunakan media gambar seri dapat mengembangkan potensi perkembangan berbicara anak, yaitu dengan cara anak dapat menyampaikan pesan terdiri dari dua atau tiga kata dan dapat memunculkan kalimat-kalimat yang lebih rumit dan dengan menggunakan gambar seri, anak yang mengalami kesulitatan dalam berbicara akan teratasi dan akan meningkatkan kemampuan siswa dalam berbicara sehingga tujuan yang diharapkan akan tercapai secara optimal.

\section{KESIMPULAN}

Berdasarkan pembahasan yang telah diuraikan, maka dapat ditarik kesimpulan bahwa Anak Usia dini merupakan masa-masa yang paling tepat dalam memberikan beragam stimulus guna mengoptimakan segala aspek perkembangannya. Hal tersebut dikarenakan pada masa usia dini merupakan masa-masa golden age, seluruh aspek perkembangannya dapat dikembangkan secara optimal. Salah satu aspek perkembangan yang dapat dioptimalkan pada masa usia dini yakni perkembangan bahasa anak seperti kemampuan berbicara.

Kemampuan berbicara dan penguasaan kosakata siswa yang menerapkan media gambar seri lebih baik dibandingkan tanpa media gambar seri. Dengan adanya media gambar seri, anak menjadi lebih tertarik untuk mengikuti pelajaran dan lebih kreatif untuk 
bercerita dengan melihat gambar yang langsung dilihat anak.

\section{UCAPAN TERIMA KASIH}

Penulis mengucapkan terima kasih kepada Kaprodi PG-PAUD yang telah memberikan dukungan non materil dan Tim Reviwer yang telah meluangkan waktunya untuk mereview serta memberikan banyak masukan sehingga jurnal ini lebih mudah dipahami jurnal ini serta teman-teman Faklutlas Ilmu Pendidikan di Universitas Pahlawan Tuanku Tambusai yang telah memberikan suntikan semangat yang luar biasa kepada penulis.

\section{DAFTAR PUSTAKA}

Angkowo, Robertes dan Kosasih, A. (2007). Optimalisasi Media Pembelajaran. Jakarta: Grasindo.

Azhar Arsyad. (2002). Media Pembelajaran. Jakarta: Raja Grafindo Persada.

Carool, Seefelt \& Barbara A, W. (2008). Pendidikan Anak Usia Dini. Jakarta: PT Indeks.

Djamarah, Syaiful Bahri clan Zain, A. (2002). Strategi Belajar Mengajar. Jakarta: PT. Reneka Cipta.

Haryadi dan Zamzani. (2000). Peningkatan Keterampilan Berbahasa Indonesia. Departemen Pendidikan dan Kebudayaan Direktorat Jenderal Pendidikan Tinggi.

Hasan, M. (2011). Pendidikan Anak Usia Dini. Yogyakarta: DIVA press.

Hurlock, E. (1978). Perkembangan Anak Jilid I. (Alih Bahasa: Agus Dharma). Jakarta: Erlangga.

Pratama, R. N., Abidin, Y., \& Ismail, M. H. (2016). Meningkatkan Keterampilan Berbicara Anak Usia Dini melalui Metode Bercerita Menggunakan Media Pop-Up Book, 1-13.

Rosmala, D. (2005). Berbagai Masalah Anak Taman Kanak-kanak. Jakarta: Departemen Pendidikan Nasional.

Tadkiroatun, M. (2009). Bercerita untuk Anak Usia Dini. Jakarta: Departemen Pendidikan Nasional.

Tarigan, H. G. (2008). Berbicara Sebagai Suatu Keterampilan Berbahasa. Bandung: Angkasa. 